\title{
OCUPAÇÕES URBANAS EM BELO HORIZONTE: CONCEITOS E EVIDÊNCIAS DAS ORIGENS DE UM MOVIMENTO SOCIAL URBANO ${ }^{1}$
}

\author{
Tiago Castelo Branco Lourenço ${ }^{2}$
}

DOI: 10.5752/P.2316-1752.2017v24n35p182-217

\section{Resumo}

Este artigo apresenta evidências históricas, sociais e políticas dos primórdios dos movimentos de ocupações urbanas que têm ocorrido na cidade de Belo Horizonte e região desde os anos 2000. Oferece desde o histórico desse tipo de luta política de acesso ao direito à cidade na capital de Minas Gerais, apresentando também as origens políticas e ideológicas dos movimentos sociais que conduzem essas ações políticas e contextualizando-as dentro da história política local. O artigo também apresenta algumas discussões conceituais que têm sido construídas e processadas entre ativistas sociais, lideranças e moradores das ocupações ur-

\footnotetext{
1. Este artigo é inspirado na dissertação "Cidade Ocupada", do Programa de Pós-Graduação em Arquitetura e Urbanismo da Escola de Arquitetura da UFMG.

2. Arquiteto e Urbanista pela PUC Minas, Mestre e doutorando em Arquitetura e Urbanismo pela UFMG, Professor do Departamento de Arquitetura e Urbanismo da PUC Minas e do Departamento de Projetos da Escola de Arquitetura da UFMG. E-mail: tcblourenco@gmail.com.
} 
banas da cidade, além de discussões sobre os processos de autonomia e heteronomia que envolvem os projetos de arquitetura e urbanismo dentro do contexto desses movimentos sociais urbanos.

Palavras-chave: Movimentos Sociais Urbanos. Moradia. Autonomia e Heteronomia. 


\section{URBAN OCCUPATIONS IN BELO HORIZONTE: CONCEPTS AND EVIDENCES OF THE ORIGINS OFAN URBAN SOCIAL MOVEMENT}

\begin{abstract}
This article presents some historical, social and political evidence of the beginnings of urban occupations movements that have occurred in the city of Belo Horizonte and the region since the 2000s features from the history of this type of access policy fight right to the city in the capital of Minas Gerais, also presenting the political and ideological origins of social movements leading these political actions, contextualized within the local political history. The article also presents some conceptual discussions that have been built and processed between social activists, leaders and residents of urban occupations in the city, as well as discussions on autonomy and heteronomy processes involving architectural design and urban planning within the context of these social urban movements.
\end{abstract}

Keywords: Urban Social Movements. Housing. Autonomy and Heteronomy.
OCUPACIONES URBANAS EN BELO HORIZONTE: CONCEPTOSY EVIDENCIAS DE LOS ORÍGENES DE UN MOVIMIENTO SOCIAL URBANO

\section{Resumen}

Este artículo presenta evidencias históricas, sociales y políticas de los primordios de los movimientos de ocupaciones urbanas que ha ocurrido en la ciudad de Belo Horizonte y región desde los años 2000. Presenta desde el histórico de este tipo de lucha política de acceso al derecho a la ciudad en la capital de Minas Gerais, presentando también los orígenes políticos e ideológicos de los movimientos sociales que conducen estas acciones políticas, contextualizando dentro de la historia política local. El artículo también presenta algunas discusiones conceptuales que han sido construidas y procesadas entre activistas sociales, liderazgos y moradores de las ocupaciones urbanas de la ciudad, además de discusiones sobre los procesos de autonomía y heteronomía que envuelven los proyectos de arquitectura y urbanismo dentro del contexto de esos movimientos sociales urbanos.

Palabras-claves: Movimientos Sociales Urbanos. Vivienda. Autonomía y Heteronomía 


\section{Introdução}

Nos últimos anos, a Região Metropolitana de Belo Horizonte $(\mathrm{RMBH})^{3}$ foi palco de diversas ocupações urbanas para fins de moradia em terrenos que estavam ociosos. A maioria dessas ocupações foi organizada por movimentos sociais, e mesmo as que se formaram por iniciativa dos moradores contam também, em diferentes momentos, com o apoio de movimentos e ativistas sociais.

Em todas as ocupações, movimentos sociais e moradores entraram em contato com profissionais de arquitetura, urbanismo e engenharia, à procura de assessoria técnica para a resolução de diferentes situações relacionadas aos territórios ocupados. As reflexões deste artigo se dão a partir dessa experiência de assessoria técnica direta aos moradores, movimentos e ativistas sociais.

A experiência como assessor técnico das ocupações permitiu a construção de uma relação de confiança com muitos atores do processo e, assim, o acesso a evidências que uma observação "passiva" dificilmente revelaria. Tive

3. RMBH - Região Metropolitana de Belo Horizonte. A RMBH é composta por 34 municípios, são eles: Baldim, Belo Horizonte, Betim, Brumadinho, Caeté, Capim Branco, Confins, Contagem, Esmeraldas, Florestal, Ibirité, Igarapé, Itaguara, Itatiaiuçu, Jaboticatubas, Juatuba, Lagoa Santa, Mário Campos, Mateus Leme, Matozinhos, Nova Lima, Nova União, Pedro Leopoldo, Raposos, Ribeirão das Neves, Rio Acima, Rio Manso, Sabará, Santa Luzia, São Joaquim de Bicas, São José da Lapa, Sarzedo, Taquaraçu de Minas e Vespasiano. 
oportunidade de participar de decisões técnicas e políticas, tanto internas às ocupações quanto em relação a agentes externos. Desse modo, este artigo apresenta uma interpretação particular de algumas percepções e reflexões dos sujeitos envolvidos nesses movimentos de ocupações urbanas com fins de moradia na RMBH. Essa condição de um pesquisador, que é também ator no processo, exige vigilância redobrada, para evitar discursos demasiadamente tendenciosos. O cruzamento de dados primários - coletados por mim - e dados de outras fontes é particularmente importante para que os argumentos sejam esclarecidos, evidenciando as posições do pesquisador frente ao objeto estudado.

186

O artigo apresenta, em um primeiro momento, as motivações que levaram à manifestação social da ocupação urbana com fins de moradia na RMBH e suas vinculações com a crítica à gestão do Estado, considerada neoliberal, e a tentativa local de conciliação desses preceitos, com políticas públicas vinculadas às diretrizes do Estado de bem-estar social. É também apresentado um histórico acerca da negligência observada nas políticas públicas em relação à habitação de interesse social no Brasil. Essa contextualização, que é quase consensual entre os estudiosos da área, é aqui retomada, sendo também compartilhada pelos agentes envolvidos nas ocupações urbanas estudadas em boa medida. 
Uma fonte importante na elaboração deste artigo foram as entrevistas com militantes dos movimentos Brigadas Populares, Movimento de Lutas em Bairros, Vilas e Favelas, Fórum de Moradia do Barreiro e Comissão Pastoral da Terra. As entrevistas foram do tipo não estruturadas, e, com alguns entrevistados, foi necessária a realização de mais de uma sessão para discussão dos temas propostos.

As entrevistas com os atores citados anteriormente foram uma oportunidade para o registro de um histórico, ainda que recente, dos eventos que motivaram as ocupações urbanas da RMBH a partir de suas perspectivas. A experiência da assessoria técnica direta tem permitido a formulação de conceitos utilizados nas disputas políticas que envolvem casos de movimento social urbano e suas possibilidades de utilização nas reflexões teóricas da arquitetura e urbanismo.

O recorte temporal deste artigo irá privilegiar as ocupações urbanas ocorridas a partir dos anos 90 do século XX. Entendo que antes desse período já ocorriam ocupações urbanas na $\mathrm{RMBH}$, porém o formato de mobilização que assume na contemporaneidade é observado a partir da Ocupação Corumbiara, ocorrida em 1996, condição esta que será esclarecida no artigo quando for detalhado o contexto de surgimento desse caso. 


\section{Uma negligência histórica}

As ações políticas de ocupação de terras urbanas não são fatos isolados, mas se inserem em uma dinâmica política e social de questionamento das instituições do Estado (CANCLINI, 2008). Essa condição, por sua vez, não existe apenas em Belo Horizonte, mas em diversos contextos do Brasil e do mundo, particularmente desde a crise econômica de 2008 e o "salvamento" de bancos e seguradoras pelos governos dos países mais ricos, que deixou evidentes as contradições do capitalismo financeirizado ${ }^{4}$. Aquelas nações que nas décadas anteriores vinham seguindo preceitos neoliberais, de responsabilidade fiscal e liberdade de mercado, foram convocadas a despender boa parte de suas economias no sistema financeiro para amortecer a crise e evitar consequências mais drásticas (como a crise econômica de 1929, que culminou na Segunda Guerra Mundial). Assim, evidenciaram que estão antes a serviço do capital do que a serviço da coletividade. Se aquele Estado de feições tecnocráticas neoliberais já vinha sendo criticado por vários grupos, a crise de 2008 fez dele uma instância questionada por setores muito mais amplos da sociedade civil. As ocupações urbanas ocorridas em Belo

\footnotetext{
4. Figura como ápice desse processo a concordata do banco de investimentos estadunidense Lehman Brothers em 15 de setembro de 2008, exigindo do governo dos EUA uma intervenção significativa no sistema financeiro global.
} 
Horizonte se inserem nesse contexto e podem ser entendidas como manifestações da insatisfação dele decorrente.

A demanda habitacional, motor e bandeira das ocupações urbanas, foi historicamente relegada a segundo plano pelo Estado brasileiro ou, quando muito, instrumentalizada para outros fins. Em Belo Horizonte, não é diferente, planejada no final do século XIX pelo engenheiro Aarão Reis, a habitação comparece desde o início como problema particular e não como problema de ordem coletiva (social) que merecesse uma atuação sistemática do Estado: o plano de Belo Horizonte previu moradias para o funcionalismo público estadual, no interior da zona urbana delimitada pela avenida 17 de dezembro (atual avenida do Contorno), mas não acomodava nem sequer os próprios trabalhadores da construção da cidade. Assim surgiram, já antes de sua inauguração, ocupações irregulares de trabalhadores pobres nos (atuais) bairros Floresta e Barro Preto, consideradas as primeiras favelas da cidade.

Até a década de 1930, esse tipo de ocupação foi tido, em Belo Horizonte e em todo o Brasil, como caso de polícia ou problema sanitário, não como resultado da negligência do Estado em relação a um direito social (BONDUKI, 2004). A partir dos anos 1940, com a criação dos fundos de pensão vinculados a diversas categorias profissionais, surgiram os primeiros conjuntos habitacionais urbanos destinados aos 
setores médios que chegam às cidades no bojo do processo de urbanização, tão característico da história brasileira na segunda metade do século XX (SINGER, 1973). As camadas mais pobres, no entanto, continuaram alijadas dessa política habitacional. Seu acesso às cidades sempre se deu em assentamentos precários nas bordas do território urbanizado. Em Belo Horizonte, as principais favelas da Região Centro-Sul, região mais consolidada da cidade, começaram a se formar também na segunda metade do século XX, ocupando áreas que não tinham valor para o mercado imobiliário local, em especial os terrenos com grande declividade, no entorno de cursos d'água e nascentes de rios (ARAÚJO SILVA, 2013).

190

No final dos anos 1950 e início dos anos 1960, houve mobilizações relevantes da sociedade civil pela inserção dessas camadas mais pobres no processo de modernização do país, a partir da premissa de justiça social. Uma pauta de reformas do Estado e da sociedade foi reconhecida como necessária para que o Brasil se tornasse "moderno". Ao lado da Reforma Agrária e de outras reformas de base, a Reforma Urbana foi uma causa levantada nesse período; porém o golpe militar de 31 de março de 1964 e o Estado autoritário a que dá origem esvaziaram as entidades da sociedade civil articuladas para a discussão e a implementação de reformas (ALVES, 1984). Alguns membros dos setores médios se posicionavam contrários ao regime de 
forma mais contundente, mas essa luta política na clandestinidade foi, por definição, exterior às instituições e resultou no máximo em políticas sociais de apaziguamento.

O Banco Nacional de Habitação (BNH) foi criado no mesmo ano de 1964, inaugurando uma política habitacional vultuosa no que concerne aos recursos financeiros, mas muito mais destinada à estabilidade da economia do que à efetiva melhoria das condições de moradia da população em geral $^{5}$. O novo contexto fez da política habitacional uma oportunidade de acumulação de capital e restringiu ainda mais o acesso dos pobres à moradia nas grandes cidades por vias formais. Com o forte crescimento econômico e urbano do país nos anos 1960 e 1970, a situação se agravou: aumentava a demanda por terra urbana e a oferta imobiliária para famílias de baixa renda era ineficiente. O resultado foi o crescimento de favelas e outras formas de ocupação em diversos graus de informalidade (MARICATO, 1987).

No final dos anos 1970, o regime militar e o modelo desenvolvimentista entravam em crise e houve uma reorganização da sociedade civil, acirrando o questionamento em relação aos direitos sociais que tinha perdido força desde 1964 (SOMARRIBA, 1996). O tema da Reforma Urbana vol-

5. Nessa fase se extingue a produção habitacional pelos Institutos de Aposentadorias e Pensões, que são unificados em um Instituto Nacional de Previdência Social (INPS), criado em 1966. 
tou a fazer parte das discussões que permeavam as instituições brasileiras. Com a redemocratização do país nos anos 1980 e a nova Constituição de 1988, houve uma institucionalização inédita dos direitos sociais no Brasil, incluindo o direito à moradia, que passava a figurar como obrigação do Estado em suas várias esferas. A promulgação do Estatuto da Cidade 13 anos depois, em 2001, regulamentou, pelo menos no nível federal, os preceitos constitucionais referentes à política urbana e à política habitacional, fundamentando juridicamente a função social da propriedade urbana e a participação da sociedade no planejamento e na gestão das cidades (o que, como se verá adiante, é de suma importância na batalha jurídica das ocupações urbanas em Belo Horizonte).

Nos anos 1990, muitos municípios da $\mathrm{RMBH}^{6}$ foram governados por partidos de centro-esquerda, entre eles o Partido dos Trabalhadores (PT), o Partido Socialista Brasileiro (PSB) e Partido Comunista do Brasil (PC do B). Em Belo Horizonte, esses três partidos chegaram ao governo em 1993, com a eleição de Patrus Ananias para prefeito. Sua administração, que se tornou modelo para outras prefeituras da metrópole, implementou preceitos e instrumentos defendidos pela sociedade civil organizada desde o final dos anos 1970 e

5. Os municípios da RMBH que vivenciaram uma gestão de centro-esquerda foram: Belo Horizonte, Betim, Contagem, Nova Lima e Sabará. 
parcialmente incorporados à Constituição Federal de 1988 (naquele momento ainda não regulamentados pelo Estatuto da Cidade).

Por outro lado, o período de redemocratização coincide com uma estagnação econômica e altos índices de inflação no Brasil (BRUM, 1998). À tendência das prefeituras de centro-esquerda em direção a uma espécie de Estado de bem-estar social se contrapôs a ideologia internacionalmente dominante do Estado neoliberal, que pouco interfere no mercado (inclusive no mercado de terras urbanas) e minimiza os investimentos públicos em programas sociais. Nesse contexto, as administrações municipais da RMBH, afinadas com o ideário da Reforma Urbana, tiveram possibilidades de ação muito restritas (BEDÊ, 2005). Havia estruturas legais e institucionais que poderiam tornar real o direito à cidade para todos, mas os resultados concretos foram muito limitados.

\section{Delimitações conceituais}

Cabe perceber as ocupações urbanas, no contexto mais amplo de meio século de pleitos pela reforma urbana, como uma fase de aparente sucesso no âmbito jurídico e institucional em cidades reais cada vez mais excludentes. A ação política das ocupações, no contexto de Belo Horizonte, tem como uma de suas motivações, justamente, o pro- 
cesso de institucionalização dos movimentos sociais mais antigos, que os fez perder a possibilidade de pressão sobre o poder público para a realização de políticas habitacionais.

É nesse contexto que o próprio termo ocupação precisa ser compreendido. Nos primeiros contatos com os movimentos sociais e os moradores das ocupações, é constante o constrangimento quando se refere ao lugar e à ação como invasão. "Não é uma invasão, é uma ocupação", eles corrigem. Não se trata apenas de uma questão semântica, mas do próprio sentido de legitimidade da mobilização.

Ocupação e invasão estão relacionadas a uma das mais importantes instituições desta sociedade: a propriedade privada. O direito à propriedade privada é considerado absoluto, estando presente na Declaração Universal dos Direitos Humanos $^{7}$ (ORGANIZAÇÃO DAS NAÇÕES UNIDAS, 1948), tanto quanto na Constituição Brasileira de $1988^{8}$ (BRASIL, 1988) e no Código Civil ${ }^{9}$ (BRASIL, 2002). Também no que diz respeito à propriedade privada da terra, urbana ou ru-

\footnotetext{
7. Declaração Universal dos Direitos Humanos de 1948 no Art. 17 diz: "1. Toda pessoa tem direito à propriedade, só ou em sociedade com outros. 2. Ninguém será arbitrariamente privado de sua propriedade."

8. Constituição da República Federativa do Brasil de 1988 no Art. 5, inciso XXII diz: "[...] é garantido o direito de propriedade."

9. Código Civil Brasileiro, Lei n 10.406/2002, Art. 1228 diz: "O proprietário tem a faculdade de usar, gozar e dispor da coisa, e o direito de reavê-la do poder de quem quer que injustamente a possua ou detenha."
} 
ral, a maioria dos juristas reafirma esse caráter absoluto, seguindo até hoje o espírito do Código Civil Brasileiro de $1916^{10}$, que dava poder de arbítrio quase irrestrito ao proprietário. Muitas decisões jurídicas recentes negligenciam o fato de que, desde a Constituição de 1988, a legislação obriga o proprietário de imóveis a dar "função social" à sua propriedade"11. O Novo Código Civil de 2002 e o Estatuto da Cidade (BRASIL, 2001) regulamentam esse preceito constitucional, mas ele está longe de ser "introjetado" pela sociedade brasileira, sendo objeto de grandes polêmicas nos tribunais pelo país.

Invasão se associa a um ato ilegítimo, hostil, que toma à força um espaço utilizado por outros, desrespeitando não só a lei, mas até as regras tácitas de convívio humano. Já ocupação significa dar utilidade a algo, tornar útil um espaço que está sem uso, que não cumpre a sua função social. Assim, o principal argumento dos assessores jurídicos das ocupações urbanas é o fato de se tratar de imóveis que estavam vagos, serviam apenas a propósitos especulativos e não cumpriam nenhuma função social. Uma propriedade privada que não atende aos ditames da lei não pode ser

10. Código Civil Brasileiro de 1916 em seu art. 524 diz: "A lei assegura ao proprietário o direito de gozar, usar e dispor de seus bens, e de reavê-los do poder de quem quer que injustamente os possua."

11. A Constituição da República Federativa do Brasil de 1988 no Art. $5^{\circ}$, inciso XXIII diz: a propriedade atenderá a sua função social. 
protegida por essa mesma lei. Assim, a ação de ocupação de um terreno vago por uma população privada do acesso à moradia faz cumprir um direito constitucional. Tal ação pode, em determinado momento, se mostrar hostil ou violenta, porém a maior violência não está no processo de ocupação por um grupo de famílias sem casa, mas no próprio fato de existirem nas cidades terrenos que cumprem apenas funções especulativas privadas, impondo a toda a sociedade o ônus de manter uma estrutura urbana ociosa, fomentando o alto preço do solo e impedindo que sejam ofertadas moradias para a população de menor renda. $\mathrm{O}$ termo ocupação remete à legitimidade que o ato de ocupar uma terra urbana proporciona a toda a cidade, muito além dos benefícios imediatos aos ocupantes, sendo assim o conceito utilizado para designar essas ações e lugares.

Outra especificação importante é a distinção entre ocupações urbanas organizadas e favelas. Essas últimas resultam de processos "espontâneos" e paulatinos de ocupação de terras com a finalidade de conseguir um espaço para se abrigar em uma cidade que não disponibiliza meios institucionais para isso. Já a ocupação (organizada) é uma ação planejada e estruturada por um ou vários movimentos sociais, com discursos e finalidades que ultrapassam a questão da moradia e pretendem uma oposição política mais ampla ao status quo. Na perspectiva desses movimentos, o termo favela desqualificaria de antemão a construção da 
legitimidade que almejam para combater a situação ilegal - mas socialmente reconhecida - de reserva de terras ociosas $^{12}$.

Quanto aos moradores das ocupações, é comum ouvir deles que não querem fazer daquele lugar uma favela. Nas ocupações urbanas, é recorrente esse temor, ele sempre se manifesta quando alguém infringe os planos urbanos previstos para os terrenos ocupados, por exemplo, mediante incorporação de áreas públicas ou áreas de preservação aos lotes individuais. A preocupação dos moradores, contudo, se deve, antes de mais nada, ao conteúdo pejorativo do termo. Aos seus olhos, estar em uma favela significa viver de forma degradante, precária e sem acesso a benfeitorias; é não estar de fato na cidade; é participar de uma "bagunça". Apenas à medida que a ação se desenrola, os moradores tendem a assumir a elaboração conceitual dos movimentos sociais e a ver a moradia como mais do que uma condição primordial de sobrevivência humana.

Uma terceira distinção importante é entre as ocupações e os loteamentos (periféricos), que constituem outra modalidade de oferta de terrenos para a população de baixa

12. Os movimentos e ativistas sociais atuantes nas ocupações também atuam em favelas e até são críticos em relação aos preconceitos que o termo carrega. Mesmo assim, consideram que a caracterização de uma ocupação como favela dificultaria sua legitimação. 
renda nas cidades brasileiras. Tais loteamentos, embora sejam quase sempre irregulares ${ }^{13}$, pressupõem a propriedade da terra pelo agente que os promove. Quando esse agente é um loteador privado, cujo objetivo é o lucro imobiliário, os moradores compram os terrenos (informalmente), sem participar de nenhuma ação política (CHINELLI, 1981). Quando são promovidos por associações de sem-casa, configurando os chamados loteamentos associativos ${ }^{14}$, os futuros moradores compram em conjunto uma gleba rural e fazem o parcelamento, para depois tentar transformá-la formalmente em área urbana, regularizar os lotes e obter os títulos individuais de propriedade. Isso envolve uma mobilização popular, mas de características distintas das atuais

13. Loteamentos regulares são aqueles aprovados nos órgãos públicos e, portanto, conformes à legislação urbanística municipal e à legislação federal. Nessa última, é particularmente relevante a Lei 6.766 de 19 de dezembro de 1979 (chamada Lei Lehmann), que obriga o loteador a oferecer, além do lote (porção de terra com acesso direto ao logradouro público), toda a mesoestrutura básica de vias públicas, escoamento das águas pluviais, iluminação pública, esgotamento sanitário, abastecimento de água potável, energia elétrica pública e domiciliar.

14. O loteamento associativo tem sido objeto de pesquisa do Grupo de Pesquisa MOM - Morar de Outras Maneiras (UFMG). As pesquisadoras Rebekah Campos e Silke Kapp mostraram essa situação na $\mathrm{RMBH}$, com destaque para cidades de Belo Horizonte, Ribeirão das Neves e Esmeraldas, onde diversos loteamentos associativos foram realizados por iniciativa do Padre Pier Luigi Bernareggi (Padre Piggi) com planos urbanos de autoria do arquiteto José Carlos Laender. Esses processos ocorreram entre as décadas de 1980 e 2000, com uma mobilização significativa da população pobre. Tratava-se, porém, de um contexto político bem diferente do atual: era o início da redemocratização do Brasil após a ditadura militar e as políticas habitacionais nos municípios da RMBH eram quase inexistentes. Hoje, as políticas habitacionais estão em boa parte dos municípios institucionalizadas, inclusive com a participação de vários movimentos sociais por moradia. 
ocupações e, sobretudo, sem embate direto com a instituição da propriedade privada da terra (CAMPOS, 2013).

Além dessas delimitações conceituais preliminares, é importante esclarecer que este artigo se situa também nas discussões do campo da arquitetura e do urbanismo acerca das práticas de projeto e planejamento.

O artigo parte do pressuposto de que as ocupações urbanas são arquiteturas, contrariando alguns praticantes do campo que apregoam o arquiteto como sujeito (autor) absoluto da criação de soluções para a produção e a apropriação do espaço. Nas experiências das ocupações urbanas em Belo Horizonte, o arquiteto é um sujeito no processo, assim como os moradores e os movimentos sociais. A arquiteta Silke Kapp (2008) apresenta uma terminologia importante nessa argumentação, "a outra produção arquitetônica":

Outra, porque está à margem das instituições jurídicas, técnicas e econômicas da nossa sociedade [...] Produção arquitetônica, porque proponho que nesta expressão, ou simplesmente no termo arquitetura, se inclua todo o espaço modificado pelo trabalho humano (KAPP; BALTAZAR; MORADO, 2008, p. 1).

A arquitetura, enquanto campo especializado do conhecimento humano, tem contradições sobre as quais a experiência nas ocupações proporciona reflexões relevantes. Entre elas está o ideal de integridade de um projeto de ar- 
quitetura. A integridade buscada no campo da arquitetura depende de uma sociedade em que as pessoas não interfiram ativamente nas construções, ou seja, um ambiente social pouco democrático (KAPP, 2006). Definitivamente, esse não é o ambiente que se encontra nas ocupações. A população que, não tendo suas demandas atendidas pelas vias formais, se organiza e promove uma nova oferta de moradias também põe em xeque, o tempo todo, a integridade do projeto técnico. O projeto é objeto de questionamentos e modificações constantes durante toda a sua elaboração e implantação.

Outra contradição do campo que permite reflexões a partir dessa experiência está relacionada à noção de autonomia. A autonomia é o direito de se autogovernar. Na origem grega do termo, se tem auto-nomos, norma ou lei própria, em contraposição ao hetero-nomos, norma ou lei de outro. Toda autonomia que um arquiteto venha a ter significa heteronomia para os outros envolvidos no processo, a começar pelos construtores. O canteiro de obras é um ambiente estranho ao arquiteto, que concebe seus desenhos como uma ordem de serviço inquestionável. Prevalece nos projetos a intransigência do verbo desenhar, conforme destaca Sérgio Ferro (2006, p.181): “O verbo desenhar aumenta sua tendência intransitiva; mediação por onde transitam ordens, só a si mesmo prefere dar passagem, numa perspectiva que endurece sua perseidade". 
Heteronomia semelhante está também no fato de os projetos serem concebidos por pessoas que não irão habitar o espaço projetado e nem os construir. Aqueles que o farão são tratados pela tradição do campo arquitetônico como usuários, não como sujeitos ativos na produção do espaço. Supostamente projetados para eles, tais espaços proporcionam poucas possibilidades de apropriação. Quando seus usos fogem ao prescrito, os arquitetos costumam protestar. Essa atitude em relação à criação na arquitetura nega a humanidade, porque os seres humanos, para os quais são elaborados os projetos, buscam o livre-arbítrio para construir sua experiência de vida e para afirmar os valores que norteiam essa experiência. Isso sem mencionar as atuais discussões sobre sustentabilidade, que deveriam favorecer espaços que permitam diferentes usos e não sejam destruídos a cada geração ou a cada nova necessidade. A resistência dos arquitetos em pensar essa experiência humana e social fica patente em várias situações. Uma das mais evidentes é a fotografia de arquitetura: a ausência de seres humanos nas imagens é regra. Outro exemplo é a atuação dos arquitetos junto ao patrimônio cultural. A dificuldade dos arquitetos de perceber que o "bem cultural" faz parte do cotidiano de pessoas que não o veem como "histórico" ou "artístico" gera conflitos recorrentes.

As heteronomias que o tradicional projeto de arquitetura gera para construtores e usuários é algo absolutamente 
imbricado no campo. Discutir essas questões dentro da prática do projeto é visto por muitos praticantes como uma negação do profissional. Tal quadro é agravado pelo percurso histórico do campo, que não conseguiu construir uma sacralização de sua atividade ou um discurso ideológico semelhante ao de outros campos mais bem-sucedidos em fazer de seus profissionais os sujeitos absolutos de determinado conhecimento (STEVENS, 2003). No entanto, apesar das resistências entre arquitetos, essa discussão deve e precisa ser levantada. A experiência do espaço se vincula às práticas culturais dos grupos humanos. Pensar a arquitetura como evento - e não como produto - é pensar a experiência gerando e definindo os espaços e se apropriando 202 deles.

Finalmente, a experiência cotidiana das diferentes classes sociais que convivem em uma ocupação urbana é um importante elemento para a reflexão. Os discursos progressistas de que movimentos e ativistas sociais são portadores, nesse contexto, muitas vezes não passam de imposições culturais entre classes em posições completamente desiguais, promovendo (des)encontros que não favorecem a autonomia dos sujeitos envolvidos.

Apontadas essas formulações conceituais que têm sido elaboradas a partir dessas experiências de assessoria técni- 
ca direta ${ }^{15}$ a moradores, a movimentos e a ativistas sociais, serão apresentados a seguir alguns testemunhos que indicam evidências do que seriam as origens das ocupações urbanas com fins de moradia ocorridas em Belo Horizonte a partir de 2008 com a Ocupação Camilo Torres.

\title{
Do mito de fundação à retomada
}

\begin{abstract}
Ainda no último ano da gestão de Patrus Ananias, em 1996, a insatisfação com esse estado de coisas deu origem à Ocupação Corumbiara ${ }^{16}$, em um terreno particular na região do Barreiro, no Vale do Jatobá. Sua organização foi feita pela Liga Operária (LOP) e pelo Partido Comunista Revolucionário (PCR). As 379 famílias participantes haviam integrado núcleos de sem-casa e vinham se engajando no
\end{abstract}

15. A experiência de assessoria técnica direta as ocupações urbanas com fins de moradia se iniciou em 2009, na Ocupação Dandara, no âmbito do Trabalho Final de Graduação em Arquitetura e Urbanismo, de minha autoria, na Pontifícia Universidade Católica de Minas Gerais. Nessa ocasião foram desenvolvidos o plano urbano, o estudo de esgotamento sanitário e o projeto de arquitetura do Centro Comunitário Dandara, sob orientação dos professores Margarete Maria de Araújo Silva (Leta) e Rogério Palhares. Esse trabalho de assessoria técnica direta tem ocorrido desde de 2012, por meio da ASF-Brasil (Arquitetos Sem Fronteiras Brasil), envolvendo vários profissionais do espaço. A partir de 2013, o El (Escritório de Integração do Departamento de Arquitetura e Urbanismo da PUC Minas) tem prestado esse assessoramento técnico por meio de projetos de extensão junto aos moradores das Ocupações da Izidora (Rosa Leão, Esperança e Vitória).

16. A Ocupação Corumbiara recebeu esse nome em homenagem aos mortos em um conflito, em 1995, entre camponeses sem terra e forças militares do Estado de Rondônia, que ficou conhecido como Massacre de Corumbiara. Existem divergências sobre os números de mortos: o governo local reconheceu 16 vítimas, mas os camponeses sem terra afirmam que morreram mais de 100 pessoas na ocasião. 
Orçamento Participativo da Habitação (OPH), mas perceberam que a oferta formal de moradias por essa via era ínfima diante da demanda. Bedê (2005, p. 221) observa que se desenvolveu, a partir disso, uma forma de organização popular até então incomum em Belo Horizonte, com demarcação regular de vias e lotes, cercamento da área, vigilância constante e revista de visitantes. Segundo Bedê (2005), a Prefeitura não quis envolver a Polícia Militar, para evitar um confronto violento. Já no imaginário dos movimentos sociais, há uma história de confronto - e, portanto, de luta direta - relacionada a essa ocupação.

Na época foi o pessoal do PCR e o pessoal da LOP, da Liga Operária. Eles tinham vindo de um processo de despejo de uma ocupação que teve em Betim, onde houve até mortes, em uma ocupação de terra a reintegração de posse é pesada. Parece que mataram dois ou três. Aí iniciaram a ocupação na Vila Corumbiara. A princípio houve uma resistência muito grande por parte da prefeitura. O Patrus, apesar de eles falarem que ele era bonzinho... no começo foi feito um cerco, a polícia ficava lá 24 horas (ENTREVISTADO 1, 2014).

Hoje, a Ocupação Corumbiara está consolidada como um bairro, em processo de regularização fundiária. Para a fase mais recente de ocupações urbanas, ela representa uma espécie de mito de fundação. Além disso, originou-se ali o $\mathrm{MLB}^{17}$, vinculado ao PCR, que também participa do ciclo 
recente. Esse movimento promoveu, em 2012, a Ocupação Eliana Silva, uma das importantes ocupações urbanas ocorrida em Belo Horizonte recentemente.

Depois da Corumbiara, as ocupações urbanas organizadas por movimentos sociais cessaram na capital mineira durante uma década. Esse momento coincide com o período em que a política habitacional da prefeitura se institucionaliza, levando os grupos de sem-casa a nutrir a esperança de acessar a casa própria por meio da prefeitura (BOIS, 2013). Entretanto foram poucos os avanços nas políticas habitacionais em Belo Horizonte e houve uma neutralização institucional dos canais participativos que deveriam servir para a luta por tais avanços. Em 26 de novembro de 2006, um grupo de 15 famílias retomou então a estratégia das ocupações e se instalou em um edifício no bairro Serra, na Zona Sul da cidade. As famílias eram provenientes da Vila do Cafezal, próxima ao local da ocupação. Essa foi batizada Caracol (aludindo ao molusco que carrega a casa nas costas) e recebeu, desde o início, o apoio das Brigadas Populares, criadas no ano anterior.

As Brigadas Populares se constituíram como movimento social a partir do Núcleo de Estudos Marxistas, fundado em 2003 e composto por intelectuais e estudantes de diversas áreas, particularmente do Direito. O objetivo do movimento é reunir militantes interessados em compreender a reali- 
dade brasileira à luz das teorias de Marx e buscar ações políticas concretas nas periferias das cidades brasileiras, a começar por Belo Horizonte. A Ocupação Caracol foi a primeira experiência concreta dessa organização política. Seus militantes relatam que a demanda Ihes foi apresentada pela população da Vila do Cafezal, que realizavam trabaIhos comunitários na região.

Foi nossa primeira experiência, primeira pauta de ocupação urbana, não foram pautas planejadas, foram pautas que surgiram dessa inserção nesse trabalho comunitário. O próprio povo ali foi nos ensinando, apontando caminhos, e nos empurrando também! Para tomar decisões e agir. (ENTREVISTADO 2, 2014)

Então essas famílias nos procuraram para falar queremos ocupar aquela casa que está abandonada na Serra, aquele prédio que está abandonado. Foi uma quarta feira, não esqueço isso. Nós queremos fazer ocupação na sexta. E a gente falou assim, Não! Calma, nós temos que estudar isso, ver quem que é o proprietário. [...] A Márcia [uma liderança] chegou e falou assim, nós vamos com ou sem vocês. Aí nós falamos, não, então vamos juntos. (ENTREVISTADO 3, 2013)

A Ocupação Caracol se manteve por menos de dois meses, mas chamou a atenção de outros movimentos sociais críticos em relação à política habitacional de Belo Horizonte. Depois do despejo, em janeiro de 2007, as Brigadas se associaram ao Fórum de Moradia do Barreiro e começaram a organizar a Ocupação João de Barro, recrutando famílias 
no Núcleo de Moradia do Barreiro, no Núcleo de Moradia do Padre Eustáquio, na Vila do Cafezal e no assentamento Novo Lajedo. Uma liderança do Fórum vê o processo como "rebelião" contra a participação nos canais institucionais da política habitacional da Prefeitura de Belo Horizonte ( $\mathrm{PBH})$.

Participo de movimentos de luta por moradia e pelo direito à cidade desde 2002. A princípio, a participação iniciou dentro da política habitacional institucional, através da participação nas reuniões do orçamento participativo de habitação. Ao longo do tempo fui percebendo que tudo isso é nada mais e nada menos que uma forma de a própria instituição dirigir o povo. E aí começou o processo de rebelião. Então essa lógica que está aí começou em 2007, quando iniciamos um processo de ocupação juntamente com as Brigadas Populares, lá na Serra, com a ocupação João de Barro, ocupando um prédio da massa falida da Construtora Encol. (ENTREVISTADO 1, 2014)

Essa primeira Ocupação João de Barro - depois chamada de João de Barro I - foi despejada depois de cinco meses. Parte das famílias seguiu para a Ocupação João de Barro II e, alguns meses depois, para a João de Barro III.

Depois teve a João de Barro II, que durou três meses naquele antigo hospital Cardiocentro, na avenida Antônio Carlos, e teve a João de Barro III, que foi uma casa ali na avenida Amazonas. Esse processo era uma continuidade, pois as famílias da João de Barro II eram as resistências da João de Barro I que foram despejadas e não tinham lugar para ir. Na João de Barro I a gente 
chegou com 150 famílias. Quando a gente foi despejado tinha umas 80. Aí para João de Barro II foram umas 40, e para João de Barro III foram umas 15. (ENTREVISTADO 3, 2013).

No entanto, já durante esse processo, a estratégia de ocupar edificações vazias (a chamada ocupação vertical) começou a ser revista em favor da ocupação de terrenos com a autoconstrução das moradias (chamada de ocupação horizontal), a exemplo da bem sucedida Ocupação Corumbiara. A motivação para a mudança estava, por um lado, no fato de as famílias provenientes do Barreiro terem pouco interesse em ocupar edifícios nas regiões Centro Sul e Pampulha, fora de suas redes sociais e abrindo mão da habitual casa unifamiliar (ENTREVISTADO 2, 2014). Por outro lado, a ocupação horizontal se apresentava como uma estratégia de luta política com maiores possibilidades de resistência à repressão e ao despejo.

A disposição para resistência numa ocupação vertical é muito menor, porque você não construiu uma casa. Você ser despejado de uma ocupação vertical é lucro, porque você fica seis meses sem pagar aluguel e não gastou nenhum centavo [...] diferente de uma ocupação horizontal, onde você constrói uma casa, você investiu, você colocou seu sangue, você tem um vínculo com o espaço, com o ambiente. O vínculo entre os moradores é maior (ENTREVISTADO 3, 2013). 


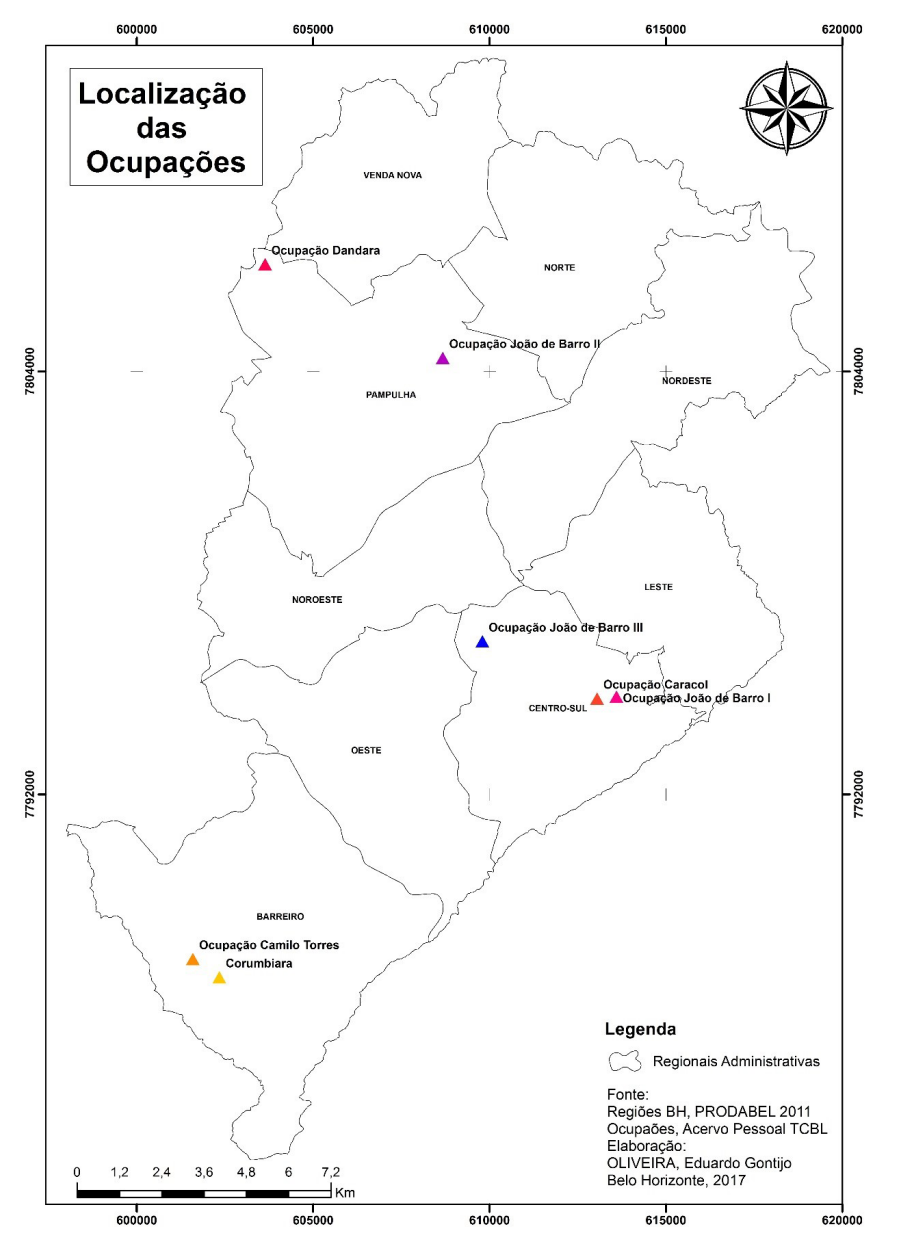


A Ocupação Camilo Torres, primeira ocupação horizontal da fase recente, se inicia então em fevereiro de 2008, sendo considerada um marco na luta política e a abertura de um novo "universo de possibilidades" (ENTREVISTADO 2, 2014).

Em fevereiro de 2008, a gente pode falar mesmo que foi o processo de resgate das ocupações. Belo Horizonte sempre foi criada através de ocupações, seja organizada ou espontânea. O mapa de Belo Horizonte foi se construindo assim. Aí, iniciou-se a ocupação Camilo Torres. Parte dela foi despejada pela Prefeitura logo no início. Nós reocupamos essa parte no mesmo ano de 2008, no início de outubro, até foi no momento da eleição. Soltamos até um manifesto interessante, falando que os nossos sonhos não cabiam dentro de uma urna, era através da luta mesmo (ENTREVISTADO 1, 2014).

$\mathrm{Na}$ fase de rediscussão das alternativas de ação política, também a relação entre moradia e geração de trabalho e renda estava em pauta. As Brigadas cogitaram, nesse contexto, as chamadas ocupações rururbanas, conjugando moradia e atividades agrícolas em terrenos (peri)urbanos. Planejava-se realizar tais ações em associação com o MST18, seguindo o exemplo das Comunas da Terra em São Paulo.

18. O MST foi fundado em 1984, na região sul do Brasil, e é um dos movimentos sociais mais expressivos no contexto brasileiro, promovendo ações em todo o território nacional. O seu trabalho político explicitou, para toda a sociedade brasileira, a luta pela reforma agrária, recebendo um grande destaque nos meios de comunicação. 
Tinha determinadas discussões de aliar essa questão do país inteiro, aliar essa questão da moradia à questão do emprego. Algumas experiências do Rio Grande do Sul, com o MTD (Movimento dos Trabalhadores Desempregados), que faziam a jogada de criar dentro das ocupações urbanas também espaços de trabalho, geração de renda, enfim. Tinham as experiências do MST (Movimento dos Sem Terra) na Grande São Paulo, das comunas da terra. Que também era a tentativa de aproximar mais da cidade. Ter atividades não agrícolas nos assentamentos. Essa era a ideia. Criando um espaço de reprodução da vida, por outra via a não ser agricultura. Manufatura, um serviço etc. Fomos lá. Visitamos duas comunas, que não foram para frente, mas foram referências para nós. A nossa ideia era fazer uma ocupação aqui. Nós tínhamos uma relação com o MST, muito forte nessa época, aprendendo com eles, tudo isso (ENTREVISTADO 2, 2014).

Nem todos consideravam a ocupação rururbana factível. Segundo um dos entrevistados (ENTREVISTADO 1, 2014), houve uma divisão entre os militantes que defendiam "a lógica de que o cara que iria morar iria plantar também" e aqueles que, como ele próprio, viam nisso uma contradição.

O cara que vai morar aqui, ele prefere vender hora de trabalho do que ele mesmo produzir. Ele tem medo de produzir e depois não dar certo e "ficar na mão". O tamanho do lote que eles [o MST] queriam dividir agredia a realidade, porque hoje até a burguesia está com dificuldade de ter esse espaço. O pessoal estava 
falando em ter meio hectare dentro da cidade. Eu falei, vocês estão brincando demais. Mas aí, fui voto vencido (ENTREVISTADO 1, 2014).

Apesar das divergências, a proposta de ocupação rururbana foi levada à frente e originou a segunda ocupação horizontal recente, a Dandara (Ver Mapa 1), que teria um papel decisivo nas lutas por moradia, com grande visibilidade na cidade, no Brasil e internacionalmente. Conforme salienta outro entrevistado, o "efeito Dandara" influenciou todas as ocupações posteriores, inclusive as espontâneas como a Rosa Leão, Vitória e Esperança, ocupações urbanas iniciadas em 2013 a partir de uma mobilização de moradores da periferia de Belo Horizonte, que nos seus primeiros momentos não contou com o apoio dos movimentos dos sem-casa da cidade.

Acho o que está animando muitas essas ocupações tidas como espontâneas, é o que eu chamo de "efeito Dandara". Espalhou nacionalmente, internacionalmente, o êxito da Dandara, que não é só Dandara, é o êxito da Camilo Torres, é o êxito da Eliana Silva, é o êxito da Guarani Kaiowá. Juntas, elas estão mostrando, sinalizando para os pobres do Brasil que quando a gente faz essa conjugação de forças, empoderar os pobres internamente, contar com movimentos sociais populares legítimos e idôneos, com um grupo de arquitetos, um grupo de advogados populares, montando uma rede de apoio, trazendo as muitas forças vivas da sociedade, isso faz uma grande diferença (ENTREVISTADO 4, 2013). 


\section{Considerações Finais}

As ocupações Corumbiara, Caracol, João de Barro I, II e III foram importantes dentro da constituição das lutas políticas das ocupações urbanas com fins de moradia em Belo Horizonte e região. Elas são sempre lembradas no cotidiano das lutas políticas pelos militantes dos movimentos sociais, sendo consideradas como momentos de amadurecimento de estratégias de luta política pelo direito à cidade.

O resgaste da história e a memória desses processos políticos são importantes como registro, já que, historicamente, as resistências são muitas vezes esquecidas e abandonadas pelo tempo, dificultando a interpretação de contradições contemporâneas, que poderiam ter nos registros do passado uma possibilidade de explicação de alguns processos.

O conteúdo que este artigo apresenta evidencia que, apesar dos equívocos que ainda perpassam as lutas políticas das ocupações urbanas, bem como as elaborações conceituais ainda possíveis de serem realizadas pelo e para os movimentos e ativistas sociais, e também para a arquitetura e o urbanismo como campo do conhecimento, toda a crítica e as suas contradições são possíveis de serem superadas e refletidas no decorrer da luta política.

Essa prática política e de assessoria técnica direta apre- 
senta ainda várias contradições que precisam ser cotidianamente refletidas e conversadas na procura de novos procedimentos e caminhos. Este artigo almeja participar dessa reflexão cotidiana e contribuir na superação dessas contradições.

\section{Referências}

ALVES, Maria Helena Moreira. Estado e Oposição no Brasil (19641984). $4^{a}$ Ed. - Petrópolis: Editora Vozes, 1984.

ARAÚJO SILVA, Margarete. Águas em meio urbano, favelas nas cabeceiras. 2013. Tese (Doutorado) - Pós-graduação em Arquitetura e Urbanismo (NPGAU), Escola de Arquitetura - UFMG, Belo Horizonte.

BEDÊ, Mônica Maria Cadaval. Trajetória da formulação e implantação da política habitacional de Belo Horizonte na gestão da Frente BH Popular 1993/1996. 2005. Dissertação (Mestrado em Geografia). Instituto de Geociências - UFMG, Belo Horizonte.

BOIS, M. C. M. S. Conselho Municipal de Habitação de Belo Horizonte e o poder sobre a deliberação das diretrizes, planos e programas da política municipal de habitação. 2013. Dissertação (Mestrado em Arquitetura e Urbanismo). Escola de Arquitetura UFMG, Belo Horizonte.

BONDUKI, N. Origens da habitação social no Brasil: arquitetura moderna, lei do inquilinato e difusão da casa própria. 4. Ed. São Paulo: Estação Liberdade, 2004.

BRASIL. Constituição (1988). Constituição da República Federativa do Brasil. 35. ed. São Paulo: Saraiva, 2009.

BRASIL. Lei n. 10.257, de 10 de julho de 2001. Regulamenta os arts. 182 e 183 da Constituição Federal, estabelece diretrizes gerais da política urbana e dá outras providências. Diário Oficial Eletrônico, 11 jul. 2001, p. 1.

BRASIL. Lei n. 10.406, de 10 de janeiro de 2002. Institui o Código Civil. Diário Oficial da União, 11 jan. 2002, p. 1. Disponível em: <http:// 
www.planalto.gov.br/ccivil_03/leis/15869.htm>. Acesso em: 15 mar. 2011.

BRUM, A. Desenvolvimento Econômico Brasileiro. Petrópolis: Vozes; ljuí: Unijuí, 1998.

CAMPOS, R. B. M. O outro loteador popular: os loteamentos populares associativos sob a participação e liderança do Padre Piggi Bernareggi. 2013. Monografia (Conclusão do curso) - Escola de Arquitetura - UFMG, Belo Horizonte.

CANCLINI, N. G. Consumidores e Cidadãos 7. ed. Rio de Janeiro: UFRJ, 2008.

CHINELLI, F. Os Loteamentos de Periferia. In: VALLADARES, L. P. (Org). Habitação em questão. 2. ed. Rio de Janeiro: Zahar, 1981. p. 49-68.

FERRO, S. Arquitetura eTrabalho Livre. São Paulo: Cosac Naif, 2006.

KAPP, S. Contra a Integridade. MDC. Revista de Arquitetura e Urbanismo, v. 1, n. 2, p. 8-11, 2006.

KAPP, S.; BALTAZAR, A. P.; MORADO, D. Arquitetura como exercício crítico: apontamentos para práticas alternativas [Architecture as Critical Exercise: Little Pointers Towards Alternative Practices]. Field: a free journal for architecture, v. 2, n. 1, p. 7-30, 2008.

MARICATO, E. A Política Habitacional do Regime Militar. Petrópolis: Vozes, 1987.

ORGANIZAÇÃO DAS NAÇÕES UNIDAS. Declaração Universal dos Direitos Humanos. 1948. Disponível em: <http://portal.mj.gov.br/ sedh/ct/legis_intern/ddh_bib_inter_universal.htm>. Acesso em: 04 ago. 2013.

SINGER, P. Economia política da urbanização. São Paulo: Brasiliense/Cebrap, 1973.

SOMARRIBA, M. Movimento reivindicatório urbano e política em Belo Horizonte. In: DULCl, O. S. (Org.). Belo Horizonte: poder, política e movimentos sociais. Belo Horizonte: C/Arte, 1996.

STEVENS, G. O círculo privilegiado: fundamentos sociais da distinção arquitetônica. Brasília: UNB, 2003. 


\section{Entrevistas}

Entrevistado 1. Entrevista Entrevistado 1. 13 fev. 2014. Entrevista concedida a Tiago Castelo Branco Lourenço.

Entrevistado 2. Entrevista Entrevistado 2. 19 nov. 2013 a. Entrevista concedida a Tiago Castelo Branco Lourenço.

Entrevistado 3. Entrevista Entrevistado 3. 07 mar. 2014. Entrevista concedida a Tiago Castelo Branco Lourenço.

Entrevistado 4. Entrevista Entrevistado 4. 18 dez. 2013. Entrevista concedida a Tiago Castelo Branco Lourenço. 
